\title{
BIOCHEMICAL CHARACTERISTICS OF THIONIC FLUVISOL LINKED TO LAND USE TYPES IN SOUHTERN VIETNAM
}

\author{
NGUYEN TAN CHUNG ${ }^{1 *}$, SY DANH CHUNG ${ }^{2}$ and HOANG VAN THOI ${ }^{2}$ \\ 'Department of Biotechnology, Nong Lam University, Ho Chi Minh City 70000, Viet Nam \\ ${ }^{2}$ Department of Centre for Fruit Tree Research, Southerm Institute of Fruit Tree Reseach, \\ My Tho 203, Viet Nam \\ ${ }^{3}$ Department of Forest Ecology and Environment, Forest Science Institute of South Viet Nam, \\ Ho Chi Minh City 70000, Viet Nam
}

Received 10 December 2016/Accepted 25 May 2017

\begin{abstract}
Thionic Fluvisols soil in Southern Vietnam is like typical acid sulfate soil in the tropics and is severely polluted due to human activities. Salinity intrusion and industrial wastewater contamination are the main cause of environmental degradation in soil ecosystem. This research was aimed to determine a link between biochemical soil properties and land use types to provide suitable solutions for afforestation and soil restoration. Soil sampling was conducted in five different land use types at four soil layers $(\mathrm{O}, \mathrm{AB}, \mathrm{Bj}$ and $\mathrm{Cp})$. The five land use types were sugarcane crop; Melaleuca plantation; 2-year Acacia plantation; 5-year Acacia plantation; and control (grass-covered land). The results showed that soil in those five land use types were very acidic $(\mathrm{pH} \leq 4)$ having poor-nutrient condition with range of orthophosphate content of $378-640 \mathrm{mg} / \mathrm{kg}, \mathrm{N}_{-} \mathrm{NH}_{4}$ of $586-999 \mathrm{mg} / \mathrm{kg}$ and $\mathrm{N}-\mathrm{NO}_{3}$ of $830-1,112 \mathrm{mg} / \mathrm{kg}$. Concentration of toxic ions was very high with large variation among land use types and soil depths i.e. 1,799 - 12,403 $\mathrm{mg} \mathrm{SO}{ }_{4}^{2-} / \mathrm{kg} ; 22$ - 1,645 mg exchangeable Fe $/ \mathrm{kg}$ and $34-88 \mathrm{mg} \mathrm{Al}^{3+} / \mathrm{kg}$ soil. The lowest concentration of exchangeable $\mathrm{Fe}^{3+}$ and $\mathrm{SO}_{4}^{2-}$ ions were found in sugarcane and Melaleuca plantations, respectively. Twenty-three sulfur-oxidizing bacteria and two iron-oxidizing bacteria were identified. All these bacteria were initially identified as Thiobacillus sp. Sugarcane and Melaleuca plantations exhibited the most diverse Thiobacillus species which linked to reduction of exchangeable $\mathrm{Fe}$ and $\mathrm{SO}_{4}^{2-}$ concentrations in these two land use types. This study indicated that Thiobacillus sp. could grow well in the Thionic Fluvisols. It is proposed that Melalenca and sugarcane species could reduce iron and sulfur contents in Thionic Fluvisols in the tropics.
\end{abstract}

Keywords: Acacia, acid sulfate soil, Melalenca; sugarcane, Thionic Fluvisols, Thiobacillus sp.

\section{INTRODUCTION}

Thionic Fluvisols are acid sulfate soils containing high $\mathrm{SO}_{4}^{2-}$ content, having very low $\mathrm{pH}$ (3 - 4) and containing high concentration of exchangeable $\mathrm{Al}^{3+}$ and $\mathrm{Fe}^{3+}$. High content of $\mathrm{SO}_{4}^{2}$ accumulating in the soil mainly originates from an oxidation of potential minerals containing sulfur to form sulfuric acid $\left(\mathrm{H}_{2} \mathrm{SO}_{4}\right)$ (Sokolova \& Alekseeva 2008). While acid sulfate soil derives from sulfides oxidation containing minerals such as organic matter, sulfate, iron and aluminum, it could be formed in brackish water soil or other highly potential sulfate soil areas with a participation of microorganisms (Dao \& Hoang 2005). Potential acid sulfate soil is a large source

*Corresponding author: ntchung@hcmuaf.edu.vn of heavy metal which causes pollution when being exposed to oxygen due to natural phenomena or artificial drainage, oxidizing pyrite to create $\mathrm{H}_{2} \mathrm{SO}_{4}$ and thus, decrease soil $\mathrm{pH}$ (Breemen 1993; Nguyen et al. 2004). Generally, iron and aluminum are often considered as toxic elements in the soils and greatly affect plant growth and development because excess of these elements can be toxic to plants (Nguyen et al. 2004; Dao \& Hoang 2005). Concentrations of exchangeable $\mathrm{Fe}\left(\mathrm{Fe}^{2+}\right.$ and $\left.\mathrm{Fe}^{3+}\right)$ and $\mathrm{Al}^{3+}$ exceeding 500 and $135 \mathrm{mg} / \mathrm{kg}$, respectively, are toxic to rice (Le et al. 2000). When soil pH is less than 4.5, macro-nutrient ions $(\mathrm{N}, \mathrm{K}, \mathrm{Ca}, \mathrm{Mg}, \mathrm{P})$ have relatively low concentration in acid soils. In contrast, $\mathrm{Al}$ and $\mathrm{Fe}$ are normally abundant in the soil with low pH (Brady \& Well 2002). The more 
acidic the soil is, the higher concentrations of these two ions are.

According to Dao and Hoang (2005), concentrations of $\mathrm{Fe}^{2+}, \mathrm{Al}^{3+}$ and $\mathrm{SO}_{4}^{2-}$ ions in acid sulfate soil are much higher than concentrations that can be tolerated by plant. Sulfur and sulfate are two main compounds involved in the formation process of acidic soil. Total sulfur in two layers of Jarosite $(B j)$ and Pyrite $(C p)$ is an index to distinguish between an acid sulfate soil and other soil types. Major forms of sulfur in the acid soil are $\mathrm{FeS}, \mathrm{FeS}_{2}, \mathrm{H}_{2} \mathrm{~S}, \mathrm{SO}_{3}^{2-}$, and $\mathrm{SO}_{4}^{2-}$. Concentration of $\mathrm{SO}_{4}^{2-}$ ions greatly varies among different types of acidic soils. $\mathrm{SO}_{4}^{2-}$ ions are toxic to plants and are obstacles for land reclamation. In Southern Vietnam, total sulfur in the acidic soil ranges from $1-4 \%$ and can reach $5-6 \%$ when the acidic soil experiences a long-term flood (Dao \& Hoang 2005). Metabolism and transformation of sulfur forms are complex with participation of sulfur-reducing bacteria in anaerobic conditions (Lamers et al. 2012; Pester et al. 2012).

A total area of potential acid sulfate soil in Southern Vietnam was 2,415,727 ha (in 2005) (Ho et al.2010). This area had active acidic soil area of 279,946 ha in 2005, which increased to $1,078,169$ ha in 2011 (Pham et al. 2011). Concentrations of $\mathrm{Fe}$ and $\mathrm{S}$ ions increased while concentrations of $\mathrm{K}^{+}, \mathrm{Al}^{3+}$, Total Organic Carbon (TOC), $\mathrm{N}$ and $\mathrm{P}$ tended to decrease between year of 1975 and 2005 (Ho et al. 2010). Kyuma (1976) and Le (2003) showed that TOC content in the acidic soil located in the Mekong Delta was pretty high, ranging from 1.0 to $4.8 \%$ for soil having high concentration of sulfur ions and ranging from 3.2 to $5.2 \%$ for soil having low concentration of sulfur ions. Due to high content of TOC, the acidic soil also contains high concentration of Total Nitrogen (TN) (0.15 $0.25 \%)$. However, concentration of Total Phosphorus (TP) $(0.01-0.05 \%)$ and Total Potassium (TK) $(0.03-0.09 \%)$ were very low in the acidic soil.

Contents of $\mathrm{Al}^{3+}, \mathrm{Fe}^{3+}, \mathrm{SO}_{4}^{2-}$ and other nutrients in acid sulfate soil greatly vary among soil layers and seasons (Le et al. 2000; Le 2003). Soil in the Mekong Delta had average organic layer depths $(\mathrm{O})$ of $20-23 \mathrm{~cm}$, transitional layer $(\mathrm{AB})$ of $23-46 \mathrm{~cm}$, Jarosite layer $(\mathrm{Bj})$ or sulfur forms producing layer of $47-88 \mathrm{~cm}$ and Pyrite layer (Bp) greater than $89 \mathrm{~cm}$ (Duong et al. 2010). Total Organic Carbon (TOC) and Total Nitrogen (TN) in layer $\mathrm{O}$ of acidic soil are $5.47 \%$ and $0.26 \%$, respectively (Ngo 2010). Other studies in Southern Vietnam conducted by Nguyen et al. (2011) showed that soil pH, TOC and TN in topsoil layer $(\mathrm{O})$ were respectively $3.38-3.75 ; 2.24$ - 4.04\%; and $0.15-0.27 \%$. Concentrations of $\mathrm{Al}^{3+}, \mathrm{Fe}^{3+}$ and $\mathrm{SO}_{4}^{2-}$ ions not only varied due to seasonal changes, but also depended on depths of soil layers (Do \& Nguyen 1999; Tran et al. 2011). Tran et al. (2011) showed concentrations of exchangeable Fe ions were seasonally fluctuated in layer $\mathrm{O}$, which could reach a peak of 11,780 $\mathrm{mg} / \mathrm{kg}$ at the beginning of the rainy season, but dramatically decreased to $521 \mathrm{mg} / \mathrm{kg}$ at the end of the rainy season while $\mathrm{Al}^{3+}$ concentration greatly varied among soil layers, fluctuated from 0 to 749 $\mathrm{mg} / \mathrm{kg}$ in soil layer A and 104 to $1,109 \mathrm{mg} / \mathrm{kg}$ soil in soil layer $\mathrm{Cp}$. Other study measuring concentrations of $\mathrm{Fe}^{2+}, \mathrm{Al}^{3+}$ and $\mathrm{SO}_{4}^{2-}$ in layer $\mathrm{Bj}$ of different acid sulfate soils in Southern Vietnam showed that $\mathrm{SO}_{4}^{2-}$ concentration was less than $0.15 \%, 0.11-0.25 \%$, and $0.27-0.74 \%$ for acidic soils having less, medium and high activity of sulfur forms; while $\mathrm{Fe}^{2+}$ and $\mathrm{Al}^{3+}$ concentrations ranged from $29-166 \mathrm{mg} / \mathrm{kg}$ and $73-111 \mathrm{mg} / \mathrm{kg}$, respectively (Ngo 2002).

Vegetation density and composition reflect soil biological property and fertility depending on soil location, type and depth (Dang et al. 2009). At soil depth of $0-22 \mathrm{~cm}$, microbial density could reach $232 \times 10^{5} \mathrm{CFU} / \mathrm{g}$, however, vegetation density was much lower at soil depth higher than $55 \mathrm{~cm}$ (Araragi \& Tangcham 1979). Hitomo \& Naoto (2005) identified four species of Thiomonas genus that could reduce sulfur from paddy rice in Sado Island of Japan, including T. cuprina, T. intermedia, $T$. perometabolis and $T$. thermosulfate. These microorganisms could transform the concentration of Thiosulfate ions from 1.51 to $1.60 \mathrm{mM}$ from initial Thiosulfate concentration of $1.61 \mathrm{mM}$ used for the cultural media (Hitomo \& Naoto 2005). Gram negative Thiobacillus isolated from paddy soil in India is highly capable of reducing sulfur forms (Rajagopal \& Sridar 2007). Results of other study conducted in acid sulfate soil in Binh Chanh District of Ho Chi Minh City showed that a total number of sulfurreducing microbes at soil depths of $0-20$ and 20 $40 \mathrm{~cm}$ ranged from $1.6 \times 10^{5}$ to $8.9 \times 10^{5} \mathrm{CFU} / \mathrm{g}$ soil (Nguyen \& Phan 1992). The study also identified Thiobacillus sp. which mainly contributed to oxidize sulfate ions and pointed out that the presence of Thiobacillus sp. 
depended on land use types and cultivation time of crops.

In order to improve acidic status of sulfate soil, some researchers planted different species on sulfate soil (Le et al. 1999; Wathinee et al. 2015; Kogawara et al. 2006). Watanabe et al. (1997) conducted trials on adaptability of Melaleuca cajuputi and Melastona marabathricum on acid sulfate soil in Thailand and observed that these species grew well. Melalenca cajuputi was capable of accumulating high aluminum concentration in its root system, while Melastona marabathricum accumulated Al in its foliage. Satoshi et al. (2006) showed that in a greenhouse condition having lack of oxygen and acidic $\mathrm{pH}$ of $5.8, M$. cajuputi grew better than E. camaldulensis. Le et al. (1999) and Thai (2009) planted Melaleuca leucadendra and Melalenca cajuputi on acid soil located in the Mekong Delta and observed that Melaleuca leucadendra and Melaleuca cajuputi could adapt to the Mekong Delta region with survival rate greater than $75 \%$.

Pham and Pham (2009) and Pham and Vu (2014) planted Eucalyptus sp. and Melaleuca sp. on seasonally inundated soil in the Mekong Delta and observed that Eucalyptus camaldulensis, Eucalyptus tereticormis, Melaleuca leucadendra, Melaleuca viridiflora and Melaleuca cajuputi could grow very well on the acid sulfate soil.

Melaleuca sp. can fix $\mathrm{Al}^{3+}$ ions into its root system through symbiosis activities of soil microorganisms associated with the root which can release organic acids to neutralize $\mathrm{Al}^{3+}$ ions (Tran 2012). This capability of Melaleuca sp. leads to the role of Melaleuca sp. in reclamation of sulfate-affected soil in the Mekong Delta.

In addition to highly adaptable Melaleuca sp. in the Mekong delta (Nakabayashi et al. 2001; Duong et al. 2005), there are many native plant species grow on acid sulfate soil in the Mekong Delta (Dang et al. 2009; Pham et al. 2014). Nine species dominating sulfate soils are Melaleuca cajeputi, Polygonum tomentosum, Nypa fruticans, Eleocharis dulcis, Nymphaea pubescens, Sonneratia caseolaris, Melastoma sp., Cryptocoryne ciliata and Annona glabra. There are several indigenous species adapting to seasonally flooded sulfate soil such as Calophyllum inophyllum, Thespesia populnea and Gluta velutina (Dang et al. 2009; Pham et al. 2014).

Environmental quality of acid sulfate soil in Southern Vietnam is seriously degraded and therefore, threatens biodiversity of the ecosystem leading to the decrease in crop production. It is important to use every possible effort to rehabilitate and restore degraded acid sulfate soil quality based on soil biochemical characteristics. Biological approach is among efforts to restore the degraded acid sulfate soil.

This study was aimed to determine biochemical characteristics of acid sulfate soil in relation to different vegetation types grown on the soil and to select appropriate crops to renovate degraded acid sulfate soil.

\section{MATERIALS AND METHODS}

Several steps were conducted to achieve the research objectives i.e. 1. measuring nutrients concentrations $(\mathrm{C}, \mathrm{N}, \mathrm{P}, \mathrm{K})$ and toxins (exchangeable $\mathrm{Fe}^{3+}, \mathrm{Al}^{3+}, \mathrm{SO}_{4}^{2-}$ ) of acid sulfate soil in Southern Vietnam; 2. isolating and identifying microorganisms that are capable of reducing sulfur and iron; and 3. evaluating potential relationship between biochemical characteristics and land use types.

\section{Study Site}

This study was conducted on five different land use types located in Binh Chanh protected forest, Binh Chanh District of Ho Chi Minh City. This location represented Thionic Fluvisols soil (acid sulfate soil) having high concentration of $\mathrm{SO}_{4}{ }^{2-}$. This area was highly polluted due to anthropogenic activities and industrial wastewater. The study site was surrounded by a canal system to water several species of plants growing in the area.

\section{Land Use Types}

Five land use types were selected for conducting sample collections i.e. sugarcane plantation, 2-year Acacia plantation, 5-year Acacia plantation, 10-year Melaleuca plantation and grass-covered land (as control; the grass was dominated by Eleocharis sp. and Cyprus sp.).

\section{Statistical Analysis}

This study was designed using Completely Randomized Design with six replications for each treatment. The treatments were the five land use 


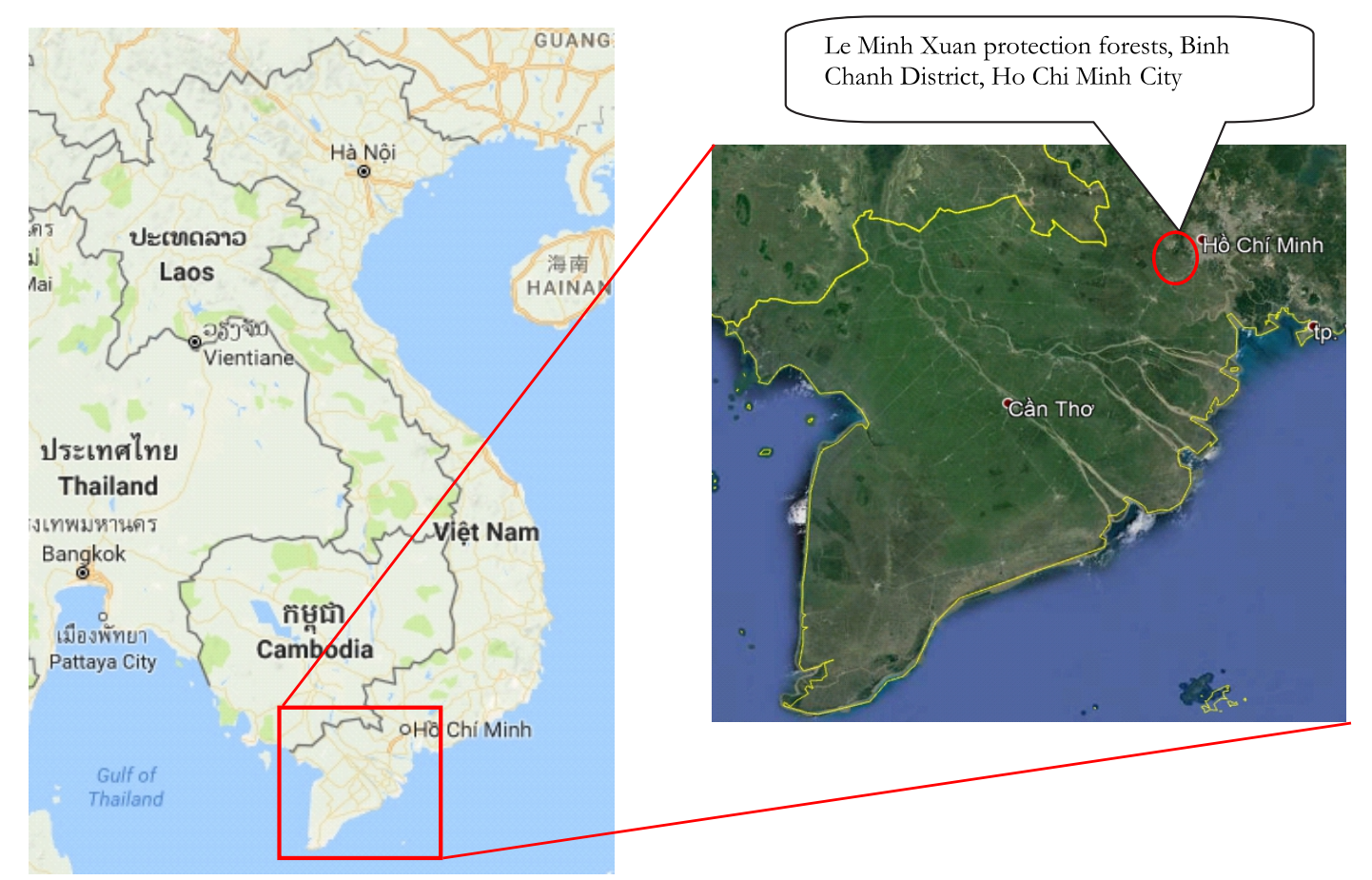

Figure 1 Study sites in the Mekong delta, Vietnam

types i.e. sugarcane plantation, 2-year Acacia plantation, 5-year Acacia plantation, 10-year Melaleuca plantation and grass-covered land (as control; the grass was dominated by Eleocharis sp. and Cyprus sp.). ANOVA of this experimental design including the Tukey's test for determining the significant differences were computed using Minitab 17 software at $p<0.05$. Sigmaplot 12 software was used to develop charts.

\section{Soil Samples Collection}

Six different soil sampling points were randomly selected in each land use type to collect soil samples and to determine soil profiles. Soil samples were collected from four soil layers i.e. $\mathrm{O}$ (organic layer), $\mathrm{AB}$ (transitional layer between $\mathrm{A}$ and $\mathrm{Bj}$ ), $\mathrm{Bj}$ (Jarosite layer) and $\mathrm{Cp}$ (Pyrite layer) (Duong et al. 2010). Soil samples were air-dried for two weeks, then were sieved using 2-mm mesh size sieve. Soil samples were analyzed at the Soil Laboratory of Forest Science Institute of South Vietnam. Macronutrient elements and toxins were analyzed from soil samples (TCVN 1995).

Different batches of soil samples for isolating and identifying microbes capable of transforming or oxidizing iron and sulfur were also collected from $O$ and $A B$ soil layers of the same soil sampling points in each land use type (Araragi \& Tangcham 1979; Nguyen \& Phan 1992).

Table 1 Analytical methods used to measure soil nutrients and toxins

\begin{tabular}{ll}
\hline \multicolumn{1}{c}{ Criteria } & \multicolumn{1}{c}{ Analytical method } \\
\hline $\mathrm{pH}$ & Soil: DDI water $=1: 5$ \\
Total Nitrogen (TN) & Kjeldahl method \\
Total Phosphorus (TP) & Dry-ashed and 6N HCl \\
Total Potassium (TK) & Dry-ashed and 6N HCl \\
Total Organic Carbon (TOC) & Walkley - Black \\
$\mathrm{NH}_{4}{ }^{+}$ & Soil: 2M KCl $=1: 10$ \\
$\mathrm{NO}_{3}^{-}$ & Soil: 2M KCl $=1: 10$ \\
$\mathrm{Orthophosphate}_{\mathrm{Al}}^{3+}$ & Mehlich 3 \\
$\mathrm{SO}_{4}{ }^{2-}$ & Mehlich 3 \\
$\mathrm{Fe}^{3+}$ & Turbidimetric method \\
\hline
\end{tabular}


Analytical methods applied for measuring macronutrients (C, N, P, K, $\mathrm{Nh}_{4}^{+}, \mathrm{NO}_{3}^{-}$, Orthophosphate) and toxic ions (Exchangeable $\mathrm{Fe}^{3+}, \mathrm{Al}^{3+}, \mathrm{SO}_{4}^{2}$ ) are presented in Table 1.

\section{Isolation and Identification of Sulfur- oxidizing Microbes}

Isolation of sulfur-oxidizing microbes was carried out based on methods described by Rajagopal and Sridar (2007), using the Starkey and Thiosulfate culture media. These culture media had initial $\mathrm{pH}$ of 8.0. The total number of sulfurreducing microbes was determined using method described by TCVN (2005) and computed using Equation 1 developed by TCVN (2005):

$A=N /\left(n_{1} V f_{1}+\ldots \ldots+n_{i} V f_{i}\right)$

where:

$$
\begin{aligned}
\mathrm{A}= & \text { numbers of bacteria cells in } 1 \mathrm{~g} \text { soil } \\
& \quad \text { (colony forming units or CFU/g) } \\
\mathrm{N}= & \text { total colony count } \\
\mathrm{n}_{\mathrm{i}}= & \text { number of disks having colony growth at } \\
& \text { each dilution } \\
\mathrm{V}= & \text { amount of sample solution in each disk } \\
\mathrm{f}_{\mathrm{i}}= & \text { dilution concentration in each disk }
\end{aligned}
$$

In order to screen microbes capable of sulfur oxidation and/or transformation, the isolated microbes were continually cultured in Thiosulfate media supplemented by three different concentrations of $\mathrm{Na}_{2} \mathrm{~S}_{2} \mathrm{O}_{3}$ i.e. 5,10 and $15 \mathrm{~g} / \mathrm{L}$ culture media.

Once screened, these microbes were tested for their biochemical characteristics such as Catalase, Voges-Proskauer (VP), Indole, Citrat, Gram, and nutritional types using methods described by Nguyen et al. (1978) and Nguyen (2005a; 2005b). The biochemical characteristics test were carried out prior to classifying and identifying these microbes. Total numbers of microbes where determined afterward.

\section{Isolation and Identification of Fe-oxidizing Microbes}

Iron-oxidizing microbes were isolated using culture media containing $1 \%$ of $\mathrm{Fe}^{2+}$ ion. This method was described by Suparna et al. (2014). Total number of Fe-reducing microbes was determined using methods described by TCVN (2005) and computed using Equation 1. The isolated microbes were continually cultured in culture media containing $3 \%$ and $6 \%$ of $\mathrm{Fe}^{2+}$ ion. These media were used to screen iron-tolerant microbes as well as microbes capable of iron oxidation. Classification and identification of the screened microbes were carried out based on growth probability test in culture media having four levels of $\mathrm{pH}$ i.e. 3, 5, 7, 9. Biochemical characteristics test was also carried out prior to classifying and identifying the microbes. The biochemical characteristics test included Catalase, Gram, mobilization ability of colonies and assimilation ability of organic carbon. Total numbers of microbes where determined afterward.

\section{RESULTS AND DISCUSSION}

\section{Soil pH}

Soil $\mathrm{pH}$ is an important indicator as it relates directly to crops development, microbial activity and biochemical reactions occurring in soils. The study results showed that soil $\mathrm{pH}$ of the five land use types were less than 4.0 (Table 2). Soil pH differed among land use types within each soil

\begin{tabular}{|c|c|c|c|c|c|}
\hline Soil layer & $\begin{array}{l}\text { Sugarcane } \\
\text { plantation }\end{array}$ & $\begin{array}{c}\text { 2-year Acacia } \\
\text { plantation }\end{array}$ & $\begin{array}{c}\text { 5-year Acacia } \\
\text { plantation }\end{array}$ & $\begin{array}{c}\text { Melaleuca } \\
\text { plantation }\end{array}$ & $\begin{array}{c}\text { Grass-covered land } \\
\text { (control) }\end{array}$ \\
\hline $\mathrm{O}$ & $3.8^{\mathrm{ab}}$ & $3.3^{b}$ & $3.5^{\mathrm{ab}}$ & $3.2^{b}$ & $3.9^{a}$ \\
\hline $\mathrm{AB}$ & $3.6^{\mathrm{ab}}$ & $2.9^{c}$ & $3.4^{\mathrm{bc}}$ & $3.5^{\mathrm{ab}}$ & $4.0^{\mathrm{a}}$ \\
\hline $\mathrm{Bj}$ & $3.5^{\mathrm{abc}}$ & $3.0^{\mathrm{c}}$ & $3.2^{\mathrm{bc}}$ & $3.6^{\mathrm{ab}}$ & $4.0^{\mathrm{a}}$ \\
\hline $\mathrm{Cp}$ & $3.3^{\mathrm{ns}}$ & $3.3^{\mathrm{ns}}$ & $3.3^{\mathrm{ns}}$ & $3.8^{\mathrm{ns}}$ & $3.7^{\mathrm{ns}}$ \\
\hline
\end{tabular}
layer of $\mathrm{O}, \mathrm{AB}$ and $\mathrm{Bj}$ (Table 2). Although sugarcane plantation and grass-covered land (control) had higher $\mathrm{pH}$ than the 2-year Acacia plantation, 5-year Acacia plantation and Melaleuca plantation, the $\mathrm{pH}$ difference was not significant.

Table 2 Soil $\mathrm{pH}$ of five land use types within each soil layer

Note: Numbers within a row (soil layer) followed by the same letter did not differ significantly at $p<0.05$ $\mathrm{ns}=$ non significantly different 


\section{Concentrations of $\mathbf{N}$ and $\mathbf{P}$ among Land Use Types}

Total Nitrogen (TN) is an important criteria used to evaluate soil fertility depending on the content of soil organic matter. Nitrogen in soil is produced by microbial decomposition of soil organic matter and is a result from fixation of nitrogen gas by rhizosphere in plant root system.

Nitrogen mainly accumulated in topsoil layer (Olayer) and AB layer for all land use types (Fig. 1). TN concentration in the topsoil layer was higher compared to those in deeper soil layers within each land use types. TN concentration ranged from $2.3 \mathrm{~g} / \mathrm{kg}$ (in sugarcane plantation) to 5.2 $\mathrm{g} / \mathrm{kg}$ (Melaleuca plantation) (Table 3).

TN concentration in topsoil layer (O layer) was slightly different from that in $\mathrm{AB}$ layer, however, it was significantly different from TN concentration in $\mathrm{Bj}$ and $\mathrm{Cp}$ layers, with exception for Melaleuca plantation and grass-covered land (control). Concentration of $\mathrm{NO}_{3}$ - ranged from $830-1,112$ $\mathrm{mg} / \mathrm{kg}$ soil, while concentration of $\mathrm{NH}_{4}{ }^{+}$ranged from 586 - $999 \mathrm{mg} / \mathrm{kg}$ soil (Table 3). Concentrations of $\mathrm{TN}, \mathrm{NO}_{3}^{-}, \mathrm{NH}_{4}^{+}$decreased with increasing soil depth (Fig. 1). The topsoil layer of Melaleuca plantation always contained the highest concentrations of TN $(5.2 \mathrm{~g} / \mathrm{kg}), \mathrm{NO}_{3}$ $\left(1,112 \mathrm{mg} / \mathrm{kg}\right.$ ) and $\mathrm{NH}_{4}^{+}(999 \mathrm{mg} / \mathrm{kg}$ soil) (Table 3). Sugarcane and 2-year Acacia plantations showed the lowest concentrations of $\mathrm{NO}_{3}$ and $\mathrm{NH}_{4}^{+}$(Table 3).

Concentrations of total phosphorus (TP) and orthophosphate in topsoil layer (O layer) were low for all land use types (Table 3; Fig. 2). Range of TP and orthophosphate concentrations in topsoil layer (O layer) were $785-958 \mathrm{mg} / \mathrm{kg}$ and $378-640 \mathrm{mg} / \mathrm{kg}$, respectively (Table 3; Fig. 2). Low concentration of orthophosphate might be due to partial binding of orthophosphate with $\mathrm{Al}^{3+}$ and $\mathrm{Fe}^{3+}$ to form Al-P and Fe-P complex (Bertsch 1996; Brady \& Well 2002). Under acidic condition $(\mathrm{pH}<4.0)$ the increase of $\mathrm{Al}^{3+}$ and $\mathrm{Fe}^{3+}$ concentrations resulted to a reduction of orthophosphate ions through Al-P and Fe-P complexation (Brady \& Well 2002). TP concentrations in topsoil layer (O layer) were not significantly different among the five land use types. The highest orthophosphate concentration was observed in the topsoil layer (O layer) of the 5-year Acacia plantation (Table 3; Fig. 2).

Table 3 Variations of $\mathrm{N}$ and $\mathrm{P}$ concentrations among land use types

\begin{tabular}{|c|c|c|c|c|c|c|c|}
\hline Criteria & $\begin{array}{l}\text { Soil } \\
\text { layer }\end{array}$ & $\begin{array}{l}\text { Sugarcane } \\
\text { crop }\end{array}$ & $\begin{array}{c}\text { 2-year Acacia } \\
\text { plantation }\end{array}$ & $\begin{array}{l}\text { 5-year Acacia } \\
\text { plantation }\end{array}$ & $\begin{array}{l}\text { Melaleuca } \\
\text { plantation }\end{array}$ & $\begin{array}{l}\text { Grass-covered } \\
\text { land (control) }\end{array}$ & $p$ value \\
\hline \multirow{4}{*}{$\begin{array}{c}\text { TN } \\
(\mathrm{g} / \mathrm{kg})\end{array}$} & $\mathrm{O}$ & $2.28^{b}$ & $2.37^{b}$ & $2.50^{\mathrm{b}}$ & $5.18^{a}$ & $2.36^{\mathrm{b}}$ & 0.002 \\
\hline & $\mathrm{AB}$ & $1.68^{\mathrm{ab}}$ & $1.96^{a}$ & $2.14^{\mathrm{a}}$ & $2.00^{\mathrm{a}}$ & $0.98^{\mathrm{b}}$ & 0.012 \\
\hline & $\mathrm{Bj}$ & $0.86^{\mathrm{b}}$ & $1.12^{\mathrm{ab}}$ & $1.19^{\mathrm{ab}}$ & $1.84^{\mathrm{a}}$ & $0.72^{\mathrm{b}}$ & 0.003 \\
\hline & $\mathrm{Cp}$ & $0.82^{\mathrm{ns}}$ & $1.98^{\mathrm{ns}}$ & $0.96^{\mathrm{ns}}$ & $1.12^{\mathrm{ns}}$ & $0.50^{\mathrm{ns}}$ & 0.091 \\
\hline \multirow{4}{*}{$\begin{array}{c}\mathrm{NH}_{4}{ }^{+} \\
(\mathrm{mg} / \mathrm{kg})\end{array}$} & $\mathrm{O}$ & $611.7^{b c}$ & $585.7^{c}$ & $861.8^{\mathrm{ab}}$ & $998.7^{a}$ & $775.2^{\mathrm{bc}}$ & 0.001 \\
\hline & $\mathrm{AB}$ & $448.5^{b}$ & $441.2^{\mathrm{b}}$ & $736.5^{a}$ & $467.3^{\mathrm{b}}$ & $386.1^{\mathrm{b}}$ & 0.003 \\
\hline & $\mathrm{Bj}$ & $133.8^{\mathrm{b}}$ & $171.1^{\mathrm{b}}$ & $504.6^{a}$ & $526.5^{\mathrm{a}}$ & $266.6^{\mathrm{b}}$ & $<0.001$ \\
\hline & $C p$ & $106.6^{\mathrm{ns}}$ & $136.9^{\text {ns }}$ & $219.0^{\mathrm{ns}}$ & $152.0^{\mathrm{ns}}$ & $227.8^{\mathrm{ns}}$ & 0.078 \\
\hline \multirow{4}{*}{$\begin{array}{c}\mathrm{NO}_{3}^{-} \\
(\mathrm{mg} / \mathrm{kg})\end{array}$} & $\mathrm{O}$ & $830.0^{\mathrm{bc}}$ & $625.1^{c}$ & $1070.1^{\mathrm{ab}}$ & $1111.8^{a}$ & $991.4^{\mathrm{ab}}$ & $<0.001$ \\
\hline & $\mathrm{AB}$ & $656.1^{\mathrm{abc}}$ & $586.1 \mathrm{bc}$ & $898.4^{a}$ & $850.7^{\mathrm{ab}}$ & $436.6^{c}$ & 0.001 \\
\hline & $\mathrm{Bj}$ & $263.4^{c}$ & $268.0^{c}$ & $599.9^{\mathrm{ab}}$ & $706.5^{a}$ & $447.3^{\mathrm{b}}$ & $<0.001$ \\
\hline & Cp & $218.1^{b}$ & $218.1^{b}$ & $294.4^{\mathrm{ab}}$ & $395.1^{\mathrm{a}}$ & $216.2^{\mathrm{b}}$ & 0.012 \\
\hline \multirow{4}{*}{$\begin{array}{c}\mathrm{TP} \\
(\mathrm{mg} / \mathrm{kg})\end{array}$} & $\mathrm{O}$ & $784.6^{\mathrm{ns}}$ & $800.6^{\mathrm{ns}}$ & $957.9^{\mathrm{ns}}$ & $871.7^{\mathrm{ns}}$ & $810.9^{\mathrm{ns}}$ & 0.118 \\
\hline & $\mathrm{AB}$ & $578.9^{\mathrm{bc}}$ & 737.7abc & $758.0^{\mathrm{ab}}$ & $535.4^{\mathrm{c}}$ & $939.8^{a}$ & $<0.001$ \\
\hline & $\mathrm{Bj}$ & $553.2^{\mathrm{bc}}$ & $687.2^{\mathrm{b}}$ & $671.3^{b}$ & $457.9^{c}$ & $905.1^{\mathrm{a}}$ & $<0.001$ \\
\hline & $\mathrm{Cp}$ & $603.9^{\mathrm{b}}$ & $628.6^{\mathrm{b}}$ & $591.1^{\mathrm{b}}$ & $519.3^{\mathrm{b}}$ & $855.7^{\mathrm{a}}$ & 0.004 \\
\hline \multirow{4}{*}{$\begin{array}{c}\mathrm{PO}_{4}{ }^{3-} \\
(\mathrm{mg} / \mathrm{kg})\end{array}$} & $\mathrm{O}$ & $493.7^{\mathrm{ab}}$ & $462.4^{b}$ & $640.0^{a}$ & $395.5^{\mathrm{b}}$ & $377.7^{\mathrm{b}}$ & 0.001 \\
\hline & $A B$ & $307.2^{\mathrm{b}}$ & $417.3^{\mathrm{ab}}$ & $461.0^{\mathrm{a}}$ & $297.3^{\mathrm{b}}$ & $303.0^{\mathrm{b}}$ & 0.002 \\
\hline & $\mathrm{Bj}$ & $280.5^{\mathrm{ab}}$ & $362.2^{\mathrm{a}}$ & $349.8^{a}$ & $274.3^{\mathrm{ab}}$ & $219.5^{\mathrm{b}}$ & 0.013 \\
\hline & $\mathrm{Cp}$ & $337.3^{a}$ & $289.0^{\mathrm{ab}}$ & $315.6^{a}$ & $249.3^{\mathrm{ab}}$ & $156.5^{\mathrm{b}}$ & 0.012 \\
\hline
\end{tabular}

Note: Numbers within a row (soil layer) followed by the same letter did not differ significantly at $p<0.05$ ns $=$ non significantly different 

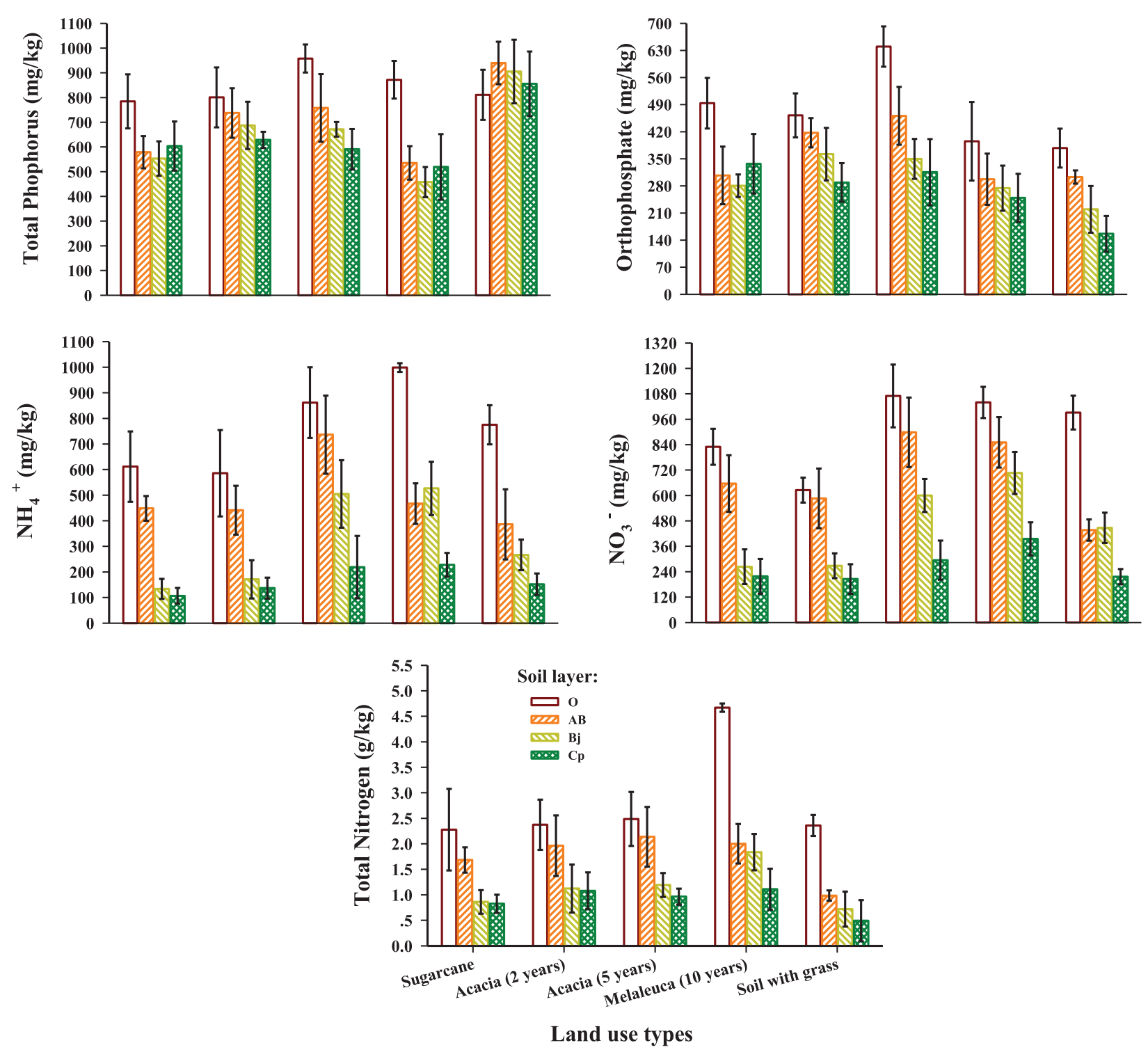

Figure 2 Concentrations of total and bioavailable $\mathrm{N}$ and $\mathrm{P}$ in five land use types

Variation of TOC and TK among Land Use Types

TOC concentration within each land use type decreased with increasing soil depth (Table 4). In each of land use types, TOC concentration in the topsoil layer was higher than those in deeper layers. Within topsoil layer, the lowest TOC concentration $(2.98 \%)$ was observed in sugarcane plantation, whereas the highest TOC concentration (5.29\%) was observed in Melaleuca plantation. Differences of TOC concentration were significantly different (Table 4). TOC concentrations in all land use types observed in this study were slightly lower than the average TOC concentration observed in previous study conducted in the Mekong Delta i.e. 5.5\% (Ngo 2010).
The lowest TK concentration was observed in Melaleuca plantation ranging from 0.494 to $0.564 \%$. Other land use types showed similar TK concentrations, ranging from 0.641 to $0.769 \%$, which was higher than TK concentration in Melaleuca plantation. Differences in TK concentration, however, were not significant. TK concentrations showed in this study were within the results of previous study conducted in the Mekong Delta (Ngo 2002). Although five land use types did not show a significant difference of TK concentrations in their topsoil layer, they were significantly different among vegetation types within taking into account of each other lower layers (AB, Bj, Cp) (Table 4).

Concentrations of TN, TP, TOC and TK were significantly lower in topsoil layer (O layer) than 
Table 4 Variations of total organic carbon (TOC) and total potassium (TK) among land use types

\begin{tabular}{|c|c|c|c|c|c|c|}
\hline Soil layer & $\begin{array}{l}\text { Sugarcane } \\
\text { crop }\end{array}$ & $\begin{array}{c}\text { 2-year Acacia } \\
\text { plantation }\end{array}$ & $\begin{array}{l}5 \text {-year Acacia } \\
\text { plantation }\end{array}$ & $\begin{array}{c}\text { Melaleuca } \\
\text { plantation }\end{array}$ & $\begin{array}{l}\text { Grass-covered land } \\
\text { (control) }\end{array}$ & $p$ value \\
\hline \multicolumn{7}{|c|}{ TOC $(\%)$} \\
\hline $\mathrm{O}$ & $2.98^{\mathrm{b}}$ & $3.08^{\mathrm{b}}$ & $3.44^{\mathrm{b}}$ & $5.29^{a}$ & $3.21^{\mathrm{b}}$ & $<0.001$ \\
\hline $\mathrm{AB}$ & $2.38^{\mathrm{bc}}$ & $2.96^{\mathrm{ab}}$ & $3.66^{\mathrm{a}}$ & $3.57^{\mathrm{ab}}$ & $1.39^{c}$ & $<0.001$ \\
\hline $\mathrm{Bj}$ & $1.29 \mathrm{~b}$ & $1.88^{\mathrm{b}}$ & $1.72^{\mathrm{b}}$ & $3.08^{a}$ & $1.71^{\mathrm{b}}$ & 0.001 \\
\hline $\mathrm{Cp}$ & $1.83^{\mathrm{ns}}$ & $2.50^{\mathrm{ns}}$ & $2.06^{\mathrm{ns}}$ & $1.89 \mathrm{~ns}$ & $2.22^{\mathrm{ns}}$ & 0.903 \\
\hline \multicolumn{7}{|c|}{$\mathrm{TK}(\%)$} \\
\hline $\mathrm{O}$ & $0.662^{\mathrm{a}}$ & $0.650^{\mathrm{a}}$ & $0.641^{\mathrm{a}}$ & $0.494^{b}$ & $0.660^{a}$ & 0.006 \\
\hline $\mathrm{AB}$ & $0.691^{\mathrm{a}}$ & $0.659^{a}$ & $0.652^{\mathrm{a}}$ & $0.511^{\mathrm{b}}$ & $0.751^{\mathrm{a}}$ & $<0.001$ \\
\hline $\mathrm{Bj}$ & $0.769^{a}$ & $0.702^{\mathrm{a}}$ & $0.696^{\mathrm{a}}$ & $0.514^{\mathrm{b}}$ & $0.696^{a}$ & $<0.001$ \\
\hline $\mathrm{Cp}$ & $0.694^{\mathrm{ab}}$ & $0.675^{\mathrm{b}}$ & $0.759^{a}$ & $0.564^{c}$ & $0.654^{b}$ & $<0.000$ \\
\hline
\end{tabular}

Note: Numbers within a row (soil layer) followed by the same letter did not differ significantly at $p<0.05$ ns $=$ non significantly different

those in deeper soil layers $(A B, B j, C p)$ within each land use type (Table $3 \& 4$ ).

Bioavailability of $\mathrm{Fe}, \mathrm{Al}$ and $\mathrm{S}$ Elements in Soil

Concentration of exchangeable $\mathrm{Fe}$ ions was particularly very low topsoil layer of sugarcane plantation (20 mg/kg soil), 2-year Acacia plantation (48 mg/kg soil) and 5-year Acacia plantation $(37 \mathrm{mg} / \mathrm{kg}$ soil). Concentration of exchangeable $\mathrm{Fe}$ ions was highly accumulated in Cp soil layer of all land use types ranging from 684 $\mathrm{mg} / \mathrm{kg}$ (in sugarcane plantation) to $2,645 \mathrm{mg} / \mathrm{kg}$ (in grass-covered land). The highest concentration of exchangeable $\mathrm{Fe}$ ions was observed in the $\mathrm{AB}, \mathrm{Bj}$ and $\mathrm{Cp}$ soil layers of
Melaleuca plantation. The lowest concentrations of $\mathrm{Al}^{3+}$ and $\mathrm{SO}_{4}^{2-}$ ions were observed in the grasscovered land (control) and Melaleuca plantation (Table 5).

Concentration of $\mathrm{SO}_{4}^{2-}$ ion in all soil layers of Melaleuca plantation was not significantly different, ranging from 3 to $4 \mathrm{~g} / \mathrm{kg}$ soil. The lowest concentration of $\mathrm{SO}_{4}{ }^{2-}$ ion was observed in the $\mathrm{AB}, \mathrm{Bj}$ and $\mathrm{Cp}$ soil layers of Melaleuca plantation. The highest concentration of $\mathrm{SO}_{4}^{2-}$ ion was observed in the 2-year Acacia plantation and 5-year Acacia plantation for all soil layers, ranging from 9.2 to $12.4 \mathrm{~g} / \mathrm{kg}$. The concentration differences within the same soil layer were not significant.

Concentration of $\mathrm{Al}^{3+}$ ion was similar within the same soil layer among five land use types.

Table 5 Variations of $\mathrm{Al}^{3+}, \mathrm{Fe}^{3+}$ and $\mathrm{SO}_{4}^{2-}$ concentrations among land use types

\begin{tabular}{cccccccc}
\hline Criteria & $\begin{array}{c}\text { Soil } \\
\text { layer }\end{array}$ & $\begin{array}{c}\text { Sugarcane } \\
\text { crop }\end{array}$ & $\begin{array}{c}\text { 2-year Acacia } \\
\text { plantation }\end{array}$ & $\begin{array}{c}5 \text {-year Acacia } \\
\text { plantation }\end{array}$ & $\begin{array}{c}\text { Melaleuca } \\
\text { plantation }\end{array}$ & $\begin{array}{c}\text { Grass-covered } \\
\text { land (control) }\end{array}$ & $p$ value \\
\hline $\mathrm{Al}^{3+}$ & $\mathrm{O}$ & $37.9^{\mathrm{ns}}$ & $49.7^{\mathrm{ns}}$ & $38.8^{\mathrm{ns}}$ & $40.7^{\mathrm{ns}}$ & $34.3^{\mathrm{ns}}$ & 0.101 \\
$(\mathrm{mg} / \mathrm{kg})$ & $\mathrm{AB}$ & $49.9^{\mathrm{ns}}$ & $56.0^{\mathrm{ns}}$ & $61.8^{\mathrm{ns}}$ & $59.0^{\mathrm{ns}}$ & $43.8^{\mathrm{ns}}$ & 0.105 \\
& $\mathrm{Bj}$ & $63.4^{\mathrm{ab}}$ & $61.2^{\mathrm{ab}}$ & $74.0^{\mathrm{a}}$ & $52.8^{\mathrm{bc}}$ & $37.5^{\mathrm{c}}$ & 0.001 \\
& $\mathrm{Cp}$ & $84.9^{\mathrm{a}}$ & $63.2^{\mathrm{ab}}$ & $68.5^{\mathrm{ab}}$ & $70.8^{\mathrm{a}}$ & $46.2^{\mathrm{b}}$ & 0.003 \\
\hline Exchangeable & $\mathrm{O}$ & $22.4^{\mathrm{c}}$ & $44.6^{\mathrm{c}}$ & $38.7^{\mathrm{c}}$ & $223.6^{\mathrm{b}}$ & $455.4^{\mathrm{a}}$ & $<0.001$ \\
$\mathrm{Fe}$ & $\mathrm{AB}$ & $16.0^{\mathrm{c}}$ & $51.0^{\mathrm{c}}$ & $35.6^{\mathrm{c}}$ & $1462.6^{\mathrm{a}}$ & $958.0^{\mathrm{b}}$ & $<0.001$ \\
$(\mathrm{mg} / \mathrm{kg})$ & $\mathrm{Bj}$ & $62.1^{\mathrm{d}}$ & $1052.8^{\mathrm{b}}$ & $489.4^{\mathrm{c}}$ & $1269.3^{\mathrm{ab}}$ & $1365.4^{\mathrm{a}}$ & $<0.001$ \\
& $\mathrm{Cp}$ & $684.6^{\mathrm{b}}$ & $1721.0^{\mathrm{a}}$ & $1692.4^{\mathrm{a}}$ & $1612.5^{\mathrm{a}}$ & $2144.9^{\mathrm{a}}$ & $<0.001$ \\
\hline $\mathrm{SO} 4^{2-}$ & $\mathrm{O}$ & $1.80^{\mathrm{c}}$ & $10.04^{\mathrm{a}}$ & $7.65^{\mathrm{b}}$ & $2.38^{\mathrm{c}}$ & $3.86^{\mathrm{c}}$ & $<0.001$ \\
$(\mathrm{~g} / \mathrm{kg})$ & $\mathrm{AB}$ & $3.24^{\mathrm{b}}$ & $9.57^{\mathrm{a}}$ & $9.00^{\mathrm{a}}$ & $3.33^{\mathrm{b}}$ & $3.45^{\mathrm{b}}$ & $<0.001$ \\
& $\mathrm{Bj}$ & $4.50^{\mathrm{b}}$ & $12.62^{\mathrm{a}}$ & $4.99^{\mathrm{b}}$ & $2.70^{\mathrm{b}}$ & $3.37^{\mathrm{b}}$ & $<0.001$ \\
& $\mathrm{Cp}$ & $10.92^{\mathrm{a}}$ & $10.93^{\mathrm{a}}$ & $8.11^{\mathrm{b}}$ & $3.94^{\mathrm{c}}$ & $8.66^{\mathrm{ab}}$ & $<0.001$ \\
\hline
\end{tabular}

Note: Numbers within a row (soil layer) followed by the same letter did not differ significantly at $p<0.05$ ns $=$ non significantly different 

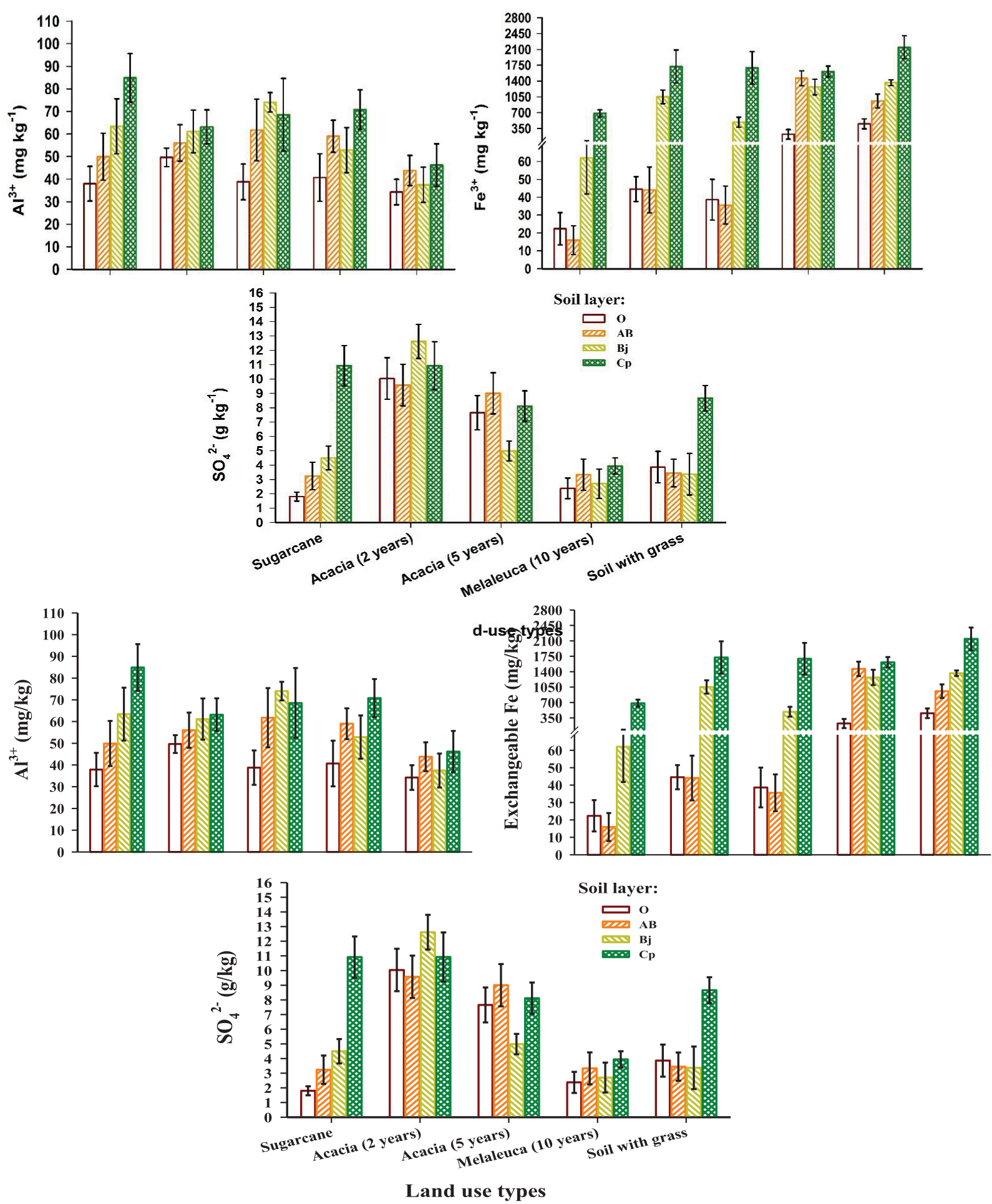

Figure 3 Concentrations of soil exchangeable $\mathrm{Fe}$ ions, $\mathrm{Al}^{3+}$ ion and $\mathrm{SO}_{4}^{2-}$ ion among land use types

Concentration of $\mathrm{Al}^{3+}$ ion increased with increasing soil depth. Range of $\mathrm{Al}^{3+}$ ion concentrations was $38-85 \mathrm{mg} / \mathrm{kg}$ for all soil layers among the five land use types. Concentrations of $\mathrm{Al}^{3+}$ ion were significantly different between $\mathrm{O}$ soil layer and $\mathrm{Cj}$ soil layer within each land use type (Table 5; Fig. 3).
Bioavailability of exchangeable Fe ions and $\mathrm{Al}^{3+}$ ion fluctuated with soil $\mathrm{pH}$ differences. Grass-covered land having higher soil $\mathrm{pH}$ exhibited lower concentration of $\mathrm{Al}^{3+}$ ion and higher concentration of exchangeable Fe ions (Dao \& Hoang 2005). 


\section{Isolation of Sulfur- and Iron-oxidizing Microbes}

Soil samples taken from $\mathrm{O}$ and $\mathrm{AB}$ soil layers were used to isolate microbes capable of reducing sulfur and iron content in the soil. Total numbers of microbes where determined afterward.

Total number of sulfur-oxidizing microbes varied from $0.75 \times 10^{5}$ to $172 \times 10^{5} \mathrm{CFU} / \mathrm{g}$ soil (Table 6). Total numbers of sulfur-oxidizing microbes isolated from the $\mathrm{O}$ soil layer were not significantly different among the five land use types. Total numbers of sulfur-oxidizing microbes isolated from the $\mathrm{AB}$ soil layer were significantly different among the five land use types. The highest number of sulfur-oxidizing microbes was recorded in soil samples taken from the $\mathrm{AB}$ soil layer of the Melaleuca plantation $\left(172 \times 10^{5}\right.$ CFU/g), followed by the -year Acacia plantation $\left(134 \times 10^{5} \mathrm{CFU} / \mathrm{g}\right)$. These results indicated that species richness and species density of sulfuroxidizing microbes were quite high among the five land use types.

Total number of iron-oxidizing microbes (range of $1.0 \times 10^{4}-4.1 \times 10^{4} \mathrm{CFU} / \mathrm{g}$ for all land use types) was much lower than those of sulfuroxidizing microbes (Table 6). Italicized numbers within brackets in Table 6 indicated the numbers of sulfur- or iron-oxidizing microbial species isolated from soil samples. These microbes survived in the sulfur- or iron-enriched culture media.

There were 23 different microbial species capable of growing well and metabolizing sulfur in sulfur-enriched culture media. Most of these microbial species were isolated from $\mathrm{O}$ layer. The highest numbers of sulfur-oxidizing microbes were found in the $\mathrm{O}$ layer of sugarcane plantation
(8 species), followed by those found in the O layer of Melaleuca plantation (6 species). Other species were found in the $\mathrm{O}$ layer of 2-year Acacia plantation ( 3 species), in the $\mathrm{O}$ layer of 5 -year Acacia plantation (3 species), in the $\mathrm{AB}$ layer of sugarcane plantation (1 species), in the AB layer of 5-year Acacia plantation (1 species) and in the $A B$ layer of grass-covered land/control (1 species). In the Starky's sulfur-enriched culture media, colonies of these microbes had yellow, orange or dark pink color with smooth surface, which are similar to the results of studies conducted by Hitomo and Naoto (2005) and Rajagopal and Sridar (2007).

Two microbial species capable of metabolizing iron in iron-enriched culture media were found in the $A B$ layer of sugarcane plantation (1 species) and in the AB layer of 5year Acacia plantation (1 species). Diameter of these iron-oxidizing microbes colonies ranged from 2 to $4 \mathrm{~mm}$. The colonies grew closely to the surface of the culture media and had goldenwhite color.

\section{Identification of Sulfur-oxidizing Microbial Genera}

Ten of the 23 sulfur-oxidizing microbial species performed high capacity of sulfur oxidation and thus, reduced $\mathrm{pH}$ of the Starkey culture media and Thiosulfate from 8.0 to 5.0 (Table 7). $\mathrm{pH} 8.0$ is the initial $\mathrm{pH}$ of the Starkey and Thiosulfate media.

All of these ten microbial species was able to transform more than $50 \%$ of $\mathrm{Na}_{2} \mathrm{~S}_{2} \mathrm{O}_{3}$ content in culture media supplemented with $5 \mathrm{mg}$ $\mathrm{Na}_{2} \mathrm{~S}_{2} \mathrm{O}_{3} / \mathrm{L}$ (Table 7).

Table 6 Total numbers of sulfur- and iron-oxidizing microbes isolated from soil samples

\begin{tabular}{cccccc}
\hline Soil layer & $\begin{array}{c}\text { Sugarcane } \\
\text { plantation }\end{array}$ & $\begin{array}{c}\text { 2-year Acacia } \\
\text { plantation }\end{array}$ & $\begin{array}{c}\text { 5-year Acacia } \\
\text { plantation }\end{array}$ & $\begin{array}{c}\text { Melalenca } \\
\text { plantation }\end{array}$ & $\begin{array}{c}\text { Grass-covered land } \\
\text { (control) }\end{array}$ \\
\hline $\mathrm{O}$ & $11.8 \times 10^{5}(8)$ & $16.8 \times 10^{5}(3)$ & $3.9 \times 10^{5}(3)$ & $0.75 \times 10^{5}(6)$ & $2.1 \times 10^{5}(0)$ \\
$\mathrm{AB}$ & $31.3 \times 10^{5}(1)$ & $134 \times 10^{5}(0)$ & $12.5 \times 10^{5}(1)$ & $172 \times 10^{5}(0)$ & $11.4 \times 10^{5}(1)$ \\
\hline & & Total sulfur-oxidizing microbes (CFU/g soil) & $1.3 \times 10^{4}$ \\
\hline $\mathrm{O}$ & $1.9 \times 10^{4}$ & $1.4 \times 10^{4}$ & $2.4 \times 10^{4}$ & $1.4 \times 10^{4}$ & $1.1 \times 10^{4}$ \\
\hline
\end{tabular}

Note: Italic numbers in the brackets are the twenty-three different species of sulfur-reducing microbes and two different species of ironreducing microbes isolated from soil samples 
BIOTROPIA Vol. 24 No. 3, 2017

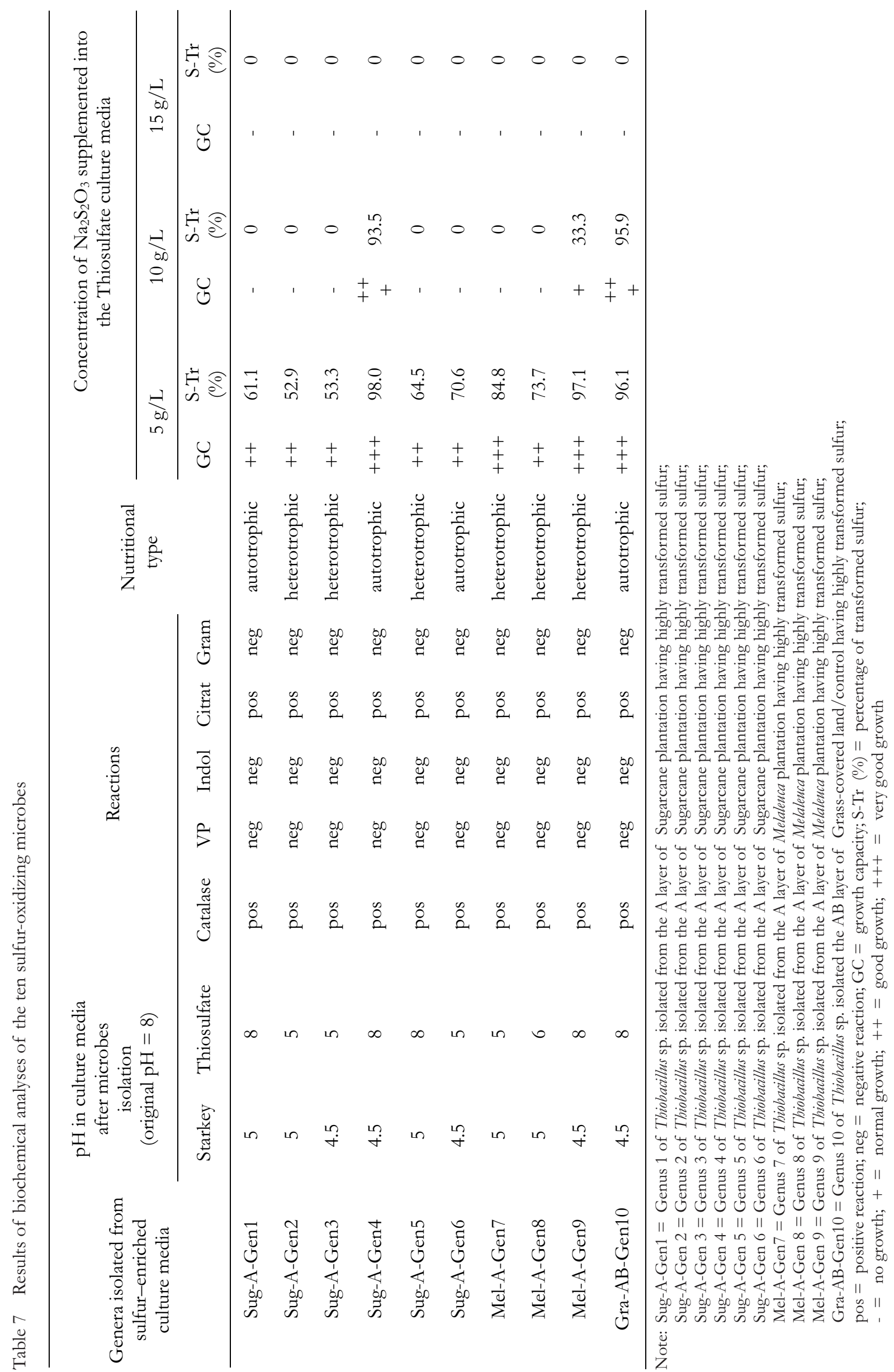


Three species were able to transform more than $96 \%$ of $\mathrm{Na}_{2} \mathrm{~S}_{2} \mathrm{O}_{3}$ in Thiosulfate culture media supplemented with $5 \mathrm{mg} \mathrm{Na} \mathrm{S}_{2} \mathrm{O}_{3} / \mathrm{L}$ i.e. Sug-AGen4, Mel-A-Gen9, and Gra-AB-Gen10 (Table 7). These three species were able to decrease $\mathrm{pH}$ of the Starkey media from 8.0 to 4.5 , however, these species were not able to decrease $\mathrm{pH}$ of Thiosulfate media (Table 7). These three species were the only species survived and grew well in Thiosulfate culture media supplemented with 10 $\mathrm{mg} \mathrm{Na}_{2} \mathrm{~S}_{2} \mathrm{O}_{3} / \mathrm{L}$, however, they did not survive in Thiosulfate culture media supplemented with 15 $\mathrm{mg} \mathrm{Na} \mathrm{S}_{2} \mathrm{O}_{3} / \mathrm{L}$ (Table 7). These three microbial species were found in the $\mathrm{O}$ and $\mathrm{AB}$ layers of sugarcane plantation, Melaleuca plantation and grass-covered land/control, and thus, would be able to oxidize sulfur in the soil of these three land use types (Fig. 3).

Results of biochemical testing for the ten sulfur-oxidizing microbial species are presented in Table 7. All of these species had negative reaction toward Gram, VP and Indol tests, however, they had positive reaction toward Catalase and Citrat tests. Nutritional test showed that the ten sulfur-oxidizing microbial species consisted of three autotrophic species from sugarcane plantation, three heterotrophic species from sugarcane plantation, one autotrophic species from grass-covered land/control and three heterotrophic species from Melaleuca plantation (Table 7).

Autotrophic microbes are microbes that can synthesize inorganic carbon sources for their growth without the presence of organic carbon compounds. Heterotrophic microbes are microbes that can only grow well in media containing high organic carbon source and cannot grow without organic carbon compounds (Brady \& Well 2002).

Identification of these ten sulfur-oxidizing microbial species was conducted based on the results of biochemical characteristics analyses, results of studies conducted by Kantachote and Innuwat (2004) and handbook of bacterial identification written by Kelly and Harrison (1989). The identification indicated that the ten sulfur-oxidizing microbial species belong to genus Thiobacillus.

\section{Identification of Iron-oxidizing Microbial Genera}

Results of biochemical testing for the two iron-oxidizing microbial species are presented in Table 8. Two iron-oxidizing microbial species were isolated from the five land use types. These two microbial species showed negative reaction toward Gram test, however, showed positive reaction toward Catalase test.

These two iron-oxidizing microbial species were initially isolated in culture media containing $1 \% \mathrm{Fe}^{2+}$. The two iron-oxidizing microbial species grew well in iron-enriched culture media having 3 and $6 \% \mathrm{Fe}^{2+}$ concentrations with culture media $\mathrm{pH} \leq 5.0$.

These two microbial species showed negative reaction toward glucose, sucrose and maltose tests, indicating that these two microbial species were autotrophic.

Identification based on biochemical characteristics analyses, results of studies conducted by Kantachote and Innuwat (2004) and handbook of bacterial identification written by Kelly and Harrison (1989) indicated that these two iron-oxidizing microbial species belong to genus Thiobacillus. 
BIOTROPIA Vol. 24 No. 3, 2017

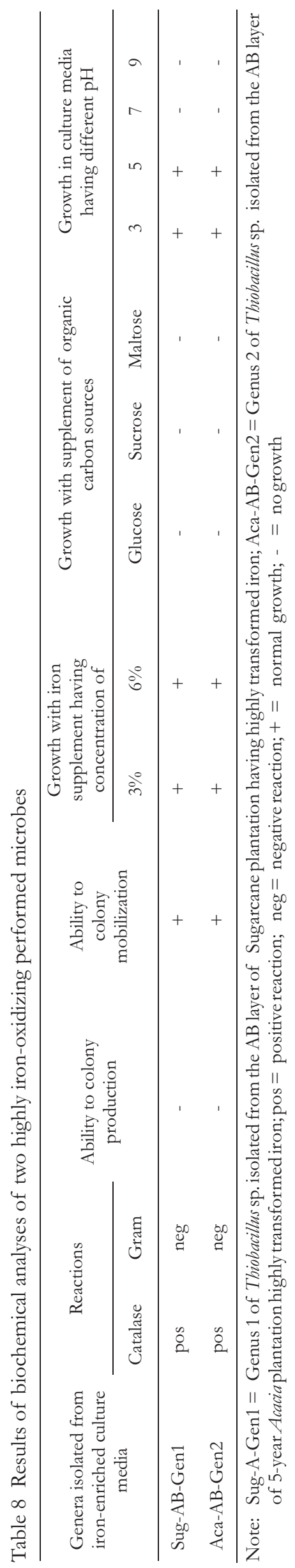




\section{CONCLUSIONS}

The five land use types had very acidic soil with soil $\mathrm{pH}$ of $\leq 4.0$, low concentrations of phosphorus and potassium. Total organic carbon (TOC) in O layers in all five land use types was higher than that in deeper soil layers. Melaleuca plantation had the highest concentration of TOC in the $\mathrm{O}$ layer. Concentrations of exchangeable $\mathrm{Fe}^{3+}, \mathrm{Al}^{3+}, \mathrm{SO}_{4}^{2-}$ ions varied among the five land use types. The lowest concentration of $\mathrm{SO}_{4}^{2-}$ was observed in the grass-covered land (control) and Melaleuca plantation.

Ten sulfur-oxidizing microbial species were isolated from sugarcane plantation, Melaleuca plantation and grass-covered land/control and were identified as belong to genus Thiobacillus.

Two iron-oxidizing microbial species were isolated from sugarcane plantation and 5-year Acacia plantation and were also identified as belong to genus Thiobacillus.

It is proposed that there is a strong relationship between Thiobacillus sp. and sugarcane plantation which indicates that Thiobacillus sp. isolated from sugarcane plantation can oxidize sulfur and iron in the polluted acid sulfate soil.

\section{ACKNOWLEDGEMENTS}

The authors thank Ho Chi Minh People Committee's Department of Forestry and Forest Science Institute of South Vietnam for providing financial support for this study.

\section{REFERENCES}

Araragi M, Tangcham B. 1979. Effect of rice straw on the composition of volatile sod gas and microflora in the tropical paddy field. J Plant Nutr Soil Sci 25:283-95.

Bertsch B. 1996. Aluminum: methods of soil analysis. Part 3chemical methods. Madison (US): Soil Sci Soc of America Inc. p. 517-50.

Brady NC, Well RR. 2002. The nature and properties of soils. New Jersey (US): Prentice Hall Inc.

Breemen V. 1993. Environmental aspects of acid sulfate soils. In: Dent DL, van Mensvoorst MEF, editors. Proceeding of symposium on acid sulfate soils in Ho Chi Minh City, March 1992. Wageningen (NL): International Institute for Land Reclamation and Improvement. Publ 53. p. 391-402.
Dang VS, Ngo T'T'T, Pham VN. 2009. Diversity of wetland ecosystems in Binh Chanh District, Ho Chi Minh City. Vietnam Wetland Association. Available from: https://vnwa.wordpress.com/2011/ 08/06/dad \% E 1\% B A \% A 1 ng - th \% E 1\% B B \% B 1 c $\mathrm{v} \% \mathrm{E} 1 \% \mathrm{BA} \% \mathrm{ADt}$-tren-h\%E1\%BB$\% 87$-sinh-thaid $\%$ E $1 \%$ B A $\%$ A 5 t - n g $\%$ E $1 \%$ B A $\%$ A D p $\mathrm{n} \% \mathrm{C} 6 \% \mathrm{~B} 0 \% \mathrm{E} 1 \% \mathrm{BB} \% 9 \mathrm{Bc}-\mathrm{huy} \% \mathrm{E} 1 \% \mathrm{BB} \% 87 \mathrm{n}-$ binh-chanh-thanh-ph\%E1\%B B \% 91 $\mathrm{h} \% \mathrm{E} 1 \% \mathrm{BB} \% 93$-chi-minh/

Dao XH, Hoang TD. 2005. Utilization and reclamation of brackish water and acidic soils. Hanoi (VN): Vietnam Publishing House of Agriculture.

Do DS, Nguyen NB. 1999. Evaluation of potential use of forest land in the Mekong Delta. Hanoi (VN): Vietnam Publishing House of Agriculture. p. 71-6.

Duong VN, Le DK, Ito J, Ngo TB. 2005. Melaleuca plantation in acid soil in the Mekong Delta and its application and role in industry. SAPROF team for Japan Bank International Cooperation (JBIC). p 5460.

Duong TN, Ngo NH, Le VP, Vo QM, Le QT. 2010. Some characteristics of acidic soil profile in the Mekong Delta. Vietnamese J Sci 14:243-9.

Hitomo O, Naoto O. 2005. Isolation and identification of sulfur-oxidizing bacteria from the buried layer containing reduced sulfur compounds of a paddy field on Sado Island. Bulletin of the Faculty of Agriculture 58:55-61. Niigata (JP): Niigata University.

Ho QD, Nguyen VD, Tran XC, Le TMH. 2010. Status of acid sulfate and mangrove soils in Mekong Delta after 30 years of utilization. Vietnamese J AgriSciTechnol 1(22):56-8.

Kantachote D, Innuwat W. 2004. Isolation of Thiobacillus sp. for use in treatment of rubber sheet wastewater. Songklanakarin J Sci Technol 26:649-57.

Kelly DP, Harrison AP. 1989. Genus of Thiobacillus sp. In: Staley GT, Penning N, Holt JG, editors. Bergey's manual of systematic bacteriology. Baltimore (US): Williams \& Wilkinson Co. p. 1842-71.

Kogawara S, Yamanoshita T, Norisada M, Masumori M, Kojima K. 2006. Photosynthesis and photoassimilate transport during root hypoxia in $M$. cajuputi, a flood-tolerant species and in E. camaldulensis, a moderate flood-tolerant species. Tree Physiol 26:1413-23.

Kyuma K. 1976. Paddy soils in the Mekong Delta of Vietnam. Discuss Pap 85. Center for Southeast Asian Studies. Kyoto (JP): Kyoto University.

Lamers LPM, van Diggelen JMH, Op den Camp HJ, Visser EJ, Lucassen EC, Vile MA, ... Roelofs JG. 2012. Microbial Transformations of Nitrogen, Sulfur, and Iron Dictate Vegetation Composition in Wetlands: A Review. Front Microbiol 3:156. doi:10.3389/ fmicb.2012.00156. 
Le HB. 2003. Based acid sulfate soil problems. Hanoi (VN): Vietnam National University's Publishing House.

Le DK, Hoang C, Nguyen TN, Pinyopusa R. 1999. Genetic selection of Melaleuca spin the Mekong Delta. Proceedings of workshop on forest plantation techniques on acid sulfate soil in Mekong Delta. For Sci Inst of South Vietnam. p. 243-53.

Le HB, Le TNH, Phan KP, Doan TY, Nguyen L. 2000. Environmental toxicology. Ho Chi Minh City (VN): HCMC National University's Publishing House.

Nakabayashi K, Nguyen NT, Thomson J, Fujita K. 2001. Effect of embankment on growth and mineral uptake of Melalenca cajuputi under acid sulfate soil condition. Soil Sci Plant Nutr 74(4):711-25.

Ngo DQ. 2002. Restoration and development of wetland and Melaleuca forests in Vietnam. Hanoi (VN): Vietnam Publishing House of Agriculture. 88 p. Available from: http://lib.dntu.edu.vn:8080/ dspace/bitstream/DNTU_123456789/1591/1/kh oi $\% 20$ phuc $\% 20$ va $\% 20$ phat $\% 20$ trien $\% 20$ rung $\% 20$ ngap $\% 20$ man $\% 20$ rung $\% 20$ tram $\% 200 \% 20$ viet $\% 20$ nam $\% 201 . p d f$

Ngo NH. 2010. Relationship between organic carbon and nitrogen in Mekong Delta's paddy soils. Vietnamese J Soil Sci 34:46-50.

Nguyen NH. 2005a. Practicing of microorganism research. Hanoi (VN): Vietnam Publishing House of Labor.

Nguyen TD. 2005b. Basis of biological microorganisms. Hanoi (VN): Vietnam Publishing House of Education.

Nguyen KQ, Lam NP, Le XT, Phan TN, Ngo NH. 2011. Effects of NPK fertilizer on sugarcane crops growing in acid soils in Hau Giang Province. Vietnamese J Sci 19b:145-57.

Nguyen TTP, Phan L. 1992. Microbiological characteristics of acid sulfate soils: a case study in the Ho Chi Minh City environment. In: Dent DL, van Mensvoorst MEF, editors. Proceeding of symposium on acid sulfate soils in Ho Chi Minh City. Wageningen (NL): International Institute for Land Reclamation and Improvement, Publ 53. p. 237-40.

Nguyen LD, Nguyen TH, Le DL, Pham TTC, Doan XM, Pham VT. 1978. Research methodologies of microorganism. Hanoi (VN): Hanoi Publishing House of Science and Technique.

Nguyen HM, Tran TK, Astrom M, Huynh CT. 2004. Pollution of some toxic metals in canal water leached out from acid sulfate soils in the Mekong Delta. In: Hiroyasu S, editors. Proceeding of the Second International Symposium on Southeast Asian Water Environment on December 2004. Ha Noi (Vietnam). Southeast Asian Water Management 2. p. 99-106.

Pester M, Knorr K-H, Friedrich MW, Wagner M, Loy A. 2012. Sulfate-Reducing Microorganisms in Wetlands - Fameless Actors in Carbon Cycling and Climate
Change. Frontiers in Microbiology 3:72. DOI:10.3389/fmicb.2012.00072.

Pham VN, Nguyen TN, Dang VS. 2014. Composition and distribution of wetland plant species in Duc Hue District, Long An Province. Vietnamese J Sci 58:5065.

Pham TD, Pham NC. 2009. Techniques of Melaleuca planation on acid sulfate based plantation in Long An province. Vietnamese Academy of Forest Sciences. Available from: http://vafs.gov.vn/vn/ 2009/03/mot-so-nghien-cuu-ve-ky-thuat-trongrung-tram-tren-dat-chua-phen-o-huyen-thanhhoa-long-an/

Pham TV, Vo QM, Le QT, Tran TT. 2011. Soils of the Mekong Delta classified by WRB-FAO classification system. Vietnamese J Sci 18b: 10-7.

Pham TD, Vu DH. 2014. Biomass of Melaleuca plantation in Long An. Vietnamese J For Sci 2:3318-23.

Rajagopal V, Sridar R. 2007. Isolation and characterization of sulfur oxidizing bacteria. J Cult Collect 5:73-7.

Satoshi K, Takashi Y, Mariko N, Masaya M, Katsumi K. 2006. Photosynthesis and photoassimilate transport during root hypoxia in Melaleuca cajuputi, a floodtolerant species, and in E. camaldulensis, a moderately flood-tolerant species. Tree Physiol 26:1453-67.

Sokolova TA, Alekseeva SA. 2008. Adsorption of Sulfate Ions by Soils (A Review). EJSS 41(2):140-148

Suparna D, Ankita P, Arti M. 2014. Isolation of a novel iron oxidizing bacteria from the iron scraps of a steel industry. Adv Appl Sci Res 5(1):277-81.

Thai TL. 2009. The research plan for improving productivity and quality of the indigenous Melaleuca species in way of hybridization with exotic species in the sulphate acid lands of seasonally fooded areas in the Mekong Delta. Vietnamese J Agric Rural Dev 3:153-61.

Tran QB. 2012. Possibility of Melaleuca forest on soil and water improvement in flooded areas of Mekong Delta. Vietnamese J Agric Rural Dev 1:95-100.

Tran NH, Dang DM, Nguyen MH. 2011. Chemical characteristics of peat soil in the surroundings area and in the core zone in U Minh Ha National Reserve of Ca Mau province. Vietnamese J Sci18b:83-91.

Vietnam Standard and Quality Insitute. 1995. TCVN 5297:1995. Soil quality and soil sampling methods. Hanoi (VN): Vietnam Standard and Quality Insitute, Directorate for Standards, Metrology and Quality.

Vietnam Standard and Quality Insitute. 2005. TCVN 4884:2005. Microorganisms in livestock food, methods in determination of total microbial number on cultural media, and technique on counting microbial colony. Hanoi (VN): Vietnam Standard and Quality Insitute, Directorate for Standards, Metrology and Quality. 
Biochemical characteristics of thionic fluvisol linked to land use types - Chung et al.

Watanabe T, Osaki M, Tadano T. 1997. Response of plants adapted in low $\mathrm{pH}$ soils to aluminum. Plant Nutr for Sustainable Food Prod Environ 78:459-60.
Wathinee S, Nuntawoot S, Waravooth S. 2015. Growth and aboveground biomass of $M$. cajuputi Plantation in Trat Province-Thailand. Thai J For 34:57-64. 